December 2019

\title{
Zine Authors' Opinions about Public and Academic Library Collections of Their Work
}

Ali N. Sadik-Ogli

School of Information, San Jose State University, ali.sadik-ogli@sjsu.edu

Follow this and additional works at: https://scholarworks.sjsu.edu/ischoolsrj

Part of the Collection Development and Management Commons

\section{Acknowledgements}

Thank you to Prof. Anthony Bernier for suggesting that this Evidence Summary might be appropriate for submission to the Journal.

\section{Recommended Citation}

Sadik-Ogli, A. N. (2019). Zine Authors' Opinions about Public and Academic Library Collections of Their Work. School of Information Student Research Journal, 9(2). https://doi.org/10.31979/2575-2499.090203 Retrieved from https://scholarworks.sjsu.edu/ischoolsrj/vol9/iss2/3

This article is brought to you by the open access Journals at SJSU ScholarWorks. It has been accepted for inclusion in School of Information Student Research Journal by an authorized administrator of SJSU ScholarWorks. For more information, please contact scholarworks@sjsu.edu. 


\section{Zine Authors' Opinions about Public and Academic Library Collections of Their Work}

\section{Keywords}

zines, zine authors, collections, collections policy

\section{Acknowledgements}

Thank you to Prof. Anthony Bernier for suggesting that this Evidence Summary might be appropriate for submission to the Journal.

About Author

Nikolai Sadik-Ogli graduated from the MLIS program at San Jose State University in May 2019. 


\section{Zine Authors' Opinions about Public and Academic Library Collections of Their Work}

\section{Citation}

Hays, A. (2018). Zine authors' attitudes about inclusion in public and academic library collections: A survey-based study. Library Quarterly, 88(1), 60-78. doi $=10.1086 / 694869$

\section{Structured Abstract}

\section{Objective}

Hays addresses the emerging phenomenon of zine collecting by public and academic libraries from the viewpoint of zine authors themselves.

\section{Setting}

Hays defines zines as intentionally nonprofessional, handmade paper publications that are written, edited, and published by the authors themselves in small print runs and sold for little, if any, profit. These factors make them both "unique and personal to the author" as well as "complicated ephemeral materials for library collections" since "their authors are often hard to track down, issues come out irregularly...often contain no bibliographic information, and...come in various paper sizes" (p. 61). Reflecting these difficulties, Hays found an admittedly limited amount of existing literature on the subject and only 113 existing institutional zine collections, which demonstrates how the field is a new phenomenon that is still growing.

\section{Design}

Hays's study concentrates on the most common academic and public library collections practices for circulation policy and access (including the type of library and its location), cataloging methods, and online metadata usage in contrast with the zine creators' most common concerns as identified in the literature review, such as acquisitions policies, privacy with regard to the use of real names versus anonymity, and the granting of permissions for research or instructional use. The study's research design was approved by the College of Staten Island's institutional review board.

\section{Subjects and Methodology}

Between December 2015 and August 2016, Hays distributed an anonymous survey through online channels that were likely to reach zine makers such as We Make Zines, an online social media community for zine writers; a zine writers electronic mailing list; Facebook pages dedicated to zine writing; and Twitter. It was also distributed in person at several zine festivals, including the NYC Feminist Zine Fest and the Chicago Zine Fest. All of the 150 respondents were over eighteen years old and self-identified as zine writers, a fact that was confirmed through a question about how many zines they actually wrote. Although American libraries were the focus of the study, participants did not need to identify as living in the United States, and Hays notes that libraries collect zines from around the world. 


\section{Findings}

Despite the potential privacy concerns mentioned above, the study found that most zine authors (83\%) actually prefer to be included in publically circulating collections instead of restrictive academic libraries. Most of the authors were also comfortable with having their zines used in classes or other work by professors and researchers, along with having their bibliographic information available and accessible online. Of course, the dissenting voices who disagreed with these approaches, such as the $7 \%$ who did not want to attach their real names to their zines in bibliographic records even though they had originally been published without pseudonyms, were quite forceful and adamant about maintaining their privacy and preventing the public from finding or accessing their work.

One of the most interesting findings in the study was the fact that the majority of zine authors preferred that their work remain in their original print-only format without digitization, yet another majority of authors would also accept digitized, online access--but only if the library asked for permission first because they often have neglected to do so in the past. Regardless of the circumstances, however, $59 \%$ of the respondents ultimately would always want their zines to be included in a library collection, and Hays considers this attitude to represent a positive response, at least from a librarians' point of view.

\section{Commentary}

Hays acknowledges that her study represents the first of its kind, and it was therefore conducted out of convenience to include only a small segment of contemporary zine authors, a population whose real numbers remain unknown. Regardless, the article is quite thorough. It provides an interesting history of zines as originating among science fiction fans in the 1930s and later as a phenomenon that expanded with the punk scene of the 1970s and again with the riot grrrl fanzines of the 1990s, which is also the decade when the first institutions started collecting them. This recent timeline creates the interesting situation in which many of the zine authors are still alive but had never thought of their ephemeral publications as being the kinds of materials that might be preserved for archival posterity or the ramifications that such preservation and greater public access might represent. Moreover, many current zine librarians were once also zine creators. In this regard, the personal nature of many zines could compromise their now-older creators' lives and professions in the present, even while many of the authors still philosophically espouse free and easy dissemination and access to all information.

Hayes' study is so recent that it does not appear to have been cited by anyone, yet. However, this novelty represents its greatest strength, since it addresses a burgeoning field of archival collecting in an important area of pop cultural media resources that continues to expand daily. It also provides hope with regard to obtaining the support and cooperation of this particular community of authors for the continued preservation of their uniquely creative and ephemeral products, while also outlining several different ways to address the community's special concerns about privacy and access to their work. Even so, in the conclusion, Hays acknowledges the limitations of this broad, initial study and recommends that future studies address specific zine topics or subgroups, such as the attitudes about 
identity that are inherently represented by zine authors who either exclusively use or do not use pseudonyms for their publications. 